\title{
NATURAL AND HUMAN IMPACT ON LAND USE CHANGE OF THE SIKKIMESE-BHUTANESE HIMALAYAN PIEDMONT, INDIA
}

\author{
PAWEe ProKop \\ Department of Geoenvironmental Research, Institute of Geography, Polish Academy of Sciences, Poland \\ SUBIR SARKAR
}

Department of Geography and Applied Geography, University of North Bengal, India

Manuscript Received: February 01, 2012

Revised Version: March 03, 2012

ProKop P., SARKAR S., Natural and human impact on land use change of the Sikkimese-Bhutanese Himalayan piedmont, India. Quaestiones Geographicae 31(3), Bogucki Wydawnictwo Naukowe, Poznań 2012, pp. 63-75. 6 Figs., 3 Tabs. DOI 10.2478/v10117-012-0010-z, ISSN 0137-477X.

AвSTRACT. Natural and human causes of land use transformation were analysed in the Sikkimese-Bhutanese Himalayan piedmont over last 150 years with special emphasize on period 1930-2010. A hydrologic and geomorphic approach was employed to delineate three study areas along river courses on alluvial fans stretching $10 \mathrm{~km}$ from the mountain front. The visual interpretation of topographic maps and satellite images combined with logical rules in GIS were used for determination of stable and dynamic areas from the viewpoint of land use changes. Analysis indicates rapid replacement of natural forest through location of tea plantations, crop cultivation and development of settlement in the late 19th century. The shift from natural to human dominated landscape caused increase land use stability through enlargement of areas with monoculture cultivation of tea and paddy between 1930 and 2010. The natural fluvial activity intensified by human induced deforestation of Himalayan margin and clearance of riparian vegetation along foothill channels became the most important factors of present-day land use changes of piedmont.

KEY wORDS: deforestation, tea garden, paddy, fluvial activity, GIS

Pawel Prokop, Department of Geoenvironmental Research, Institute of Geography, Polish Academy of Sciences, Jana 22, 31-018 Krakow, Poland, e-mail: pawel@zg.pan.krakow.pl

\section{Introduction}

The tropical areas have long history of land use and land cover (LULC) change that links together natural and human systems (Chowdhury \& Turner II 2006, An \& Carr 2012). These human- environment interactions characterized multi-dimensional complexity with many feedbacks and nonlinear processes (DeFries et al. 2010, An 2012). LULC changes may affect the climate whilst climatic change will also influence future land use (Turner II, 2001, Geist \& Lambin 2006, DeFries 
2008). The large-scale deforestations and subsequent transformations of agricultural land in the tropics are examples of land-use change with strong likely impacts on biodiversity, soil degradation and the earth's ability to support human needs (Lambin et al., 2003). The literature on tropical deforestation recognize many proximate causes (most common are agricultural expansion, timber extraction and infrastructure development) and underlying driving forces (demographic, socioeconomic, technological, political-economic and environmental) of LULC change acting in various combinations (Mather \& Needle 2000, Turner et al. 2001, Geist \& Lambin 2002, Carr et al. 2006, Davidar et al. 2010). On a smaller scale, there is great diversity of human-environment interactions with varied patterns across regions and nations. Himalayas and its thick settled foothills can be example of such coupled natural and human system complexity (Tiwari 2000, Persha et al. 2010, Zvoleff \& An 2012).

The Sikkimese-Bhutanese Himalayan piedmont called Dooars (doorways to Bhutan), with a system of alluvial fans fragmented by the dense drainage system, represent a transitional zone between mountains and lowland plains. The area, under strong influence of adjacent mountains, creates specific environmental conditions favourable or restrictive for certain forms of land use.

The nature and extent of Himalayan impact on piedmont is largely a product of adjustments in fluxes of water and sediment (Froehlich \& Starkel 1987, Starkel \& Basu 2000, Grujic et al. 2006, Soja \& Starkel 2007, Ghosh \& Carranza 2010). Both are frequently accelerated by various forms of human activity such agriculture, timber harvest, mineral extraction or road building at the mountain margin (Froehlich, Starkel 1993, Sarkar 1996, Tiwari 2000). The transfer of additional water and sediment into drainage network increases the flood risk, river bank erosion and shifting their braided courses leading to direct changes LULC system of piedmont (Nakata 1972, Starkel \& Sarkar 2002, Froehlich \& Walling 2007, Sarkar 2008, Starkel et al. 2008).

The LULC system of Sikkimese-Bhutanese Himalayan piedmont undergone rapid transformation when the British East India Company took control of Bengal in the mid-19 $9^{\text {th }}$ century. Since then there has been large-scale deforesta- tion, initiated through the foundation of tea plantations, settlement development and crop cultivation (Hunter 1876, Allen et al. 1906, Ray 2002).

The present-day economy of piedmont depends mainly on tea estates. Cultivation of other crops (paddy, millet) is done for local consumption (Bhandari \& Kale 2009). A significant part of piedmont area constitutes reserved forest, national parks and wildlife sanctuaries. Forestry based on valuable commercial trees such as sal and tourism are an important contributor to the economy and also employer of a number of people (Champion \& Seth 1968, Madhusudan 2011).

The aim of present study is analysis of land use development of the Himalayan piedmont and changes in agricultural region with special emphasis on period 1930-2010. Based on the delimitation of stable and dynamic areas from the viewpoint of LULC, the relative role of natural forces and human impact on land use is assessed.

\section{Study area}

The present study is concentrated in the piedmont of the Sikkimese-Bhutanese Himalaya, between the Tista and Kaljani rivers in the Jalpaiguri District of the West Bengal state (Fig. 1, Table 1). Quaternary piedmont deposits built a system of fans decreasing in elevation from 500-300 m a.s.l. at the mountain front to about $100 \mathrm{~m}$ a.s.l. within a distance of $15 \mathrm{~km}$. The alluvial surface is dissected by braided rivers and forms several extensive terraces. The higher elevated terraces are stable landforms, and lower ones are frequently flooded in effect of heavy monsoon rains reaching 4,000-6,000 mm annually. More than $80 \%$ of rain falls during the summer monsoon from May to October. This period is also characterized by frequent extreme events with 10-15 days exceeding $50 \mathrm{~mm}$ of rainfall (90 percentile) every year (Sarkar 2004, Soja \& Starkel 2007, Bookhagen 2010). Several days of continuous rainfall cause extreme floods with a frequency of 20-30 years, while local floods are observed every 5-10 years (Starkel \& Basu 2000, Starkel \& Sarkar, 2002, Sarkar 2008). During such events water level rise in river channels up to $6 \mathrm{~m}$ and a heavy sediment load is deposited on floodplains (Dhar \& Nan- 


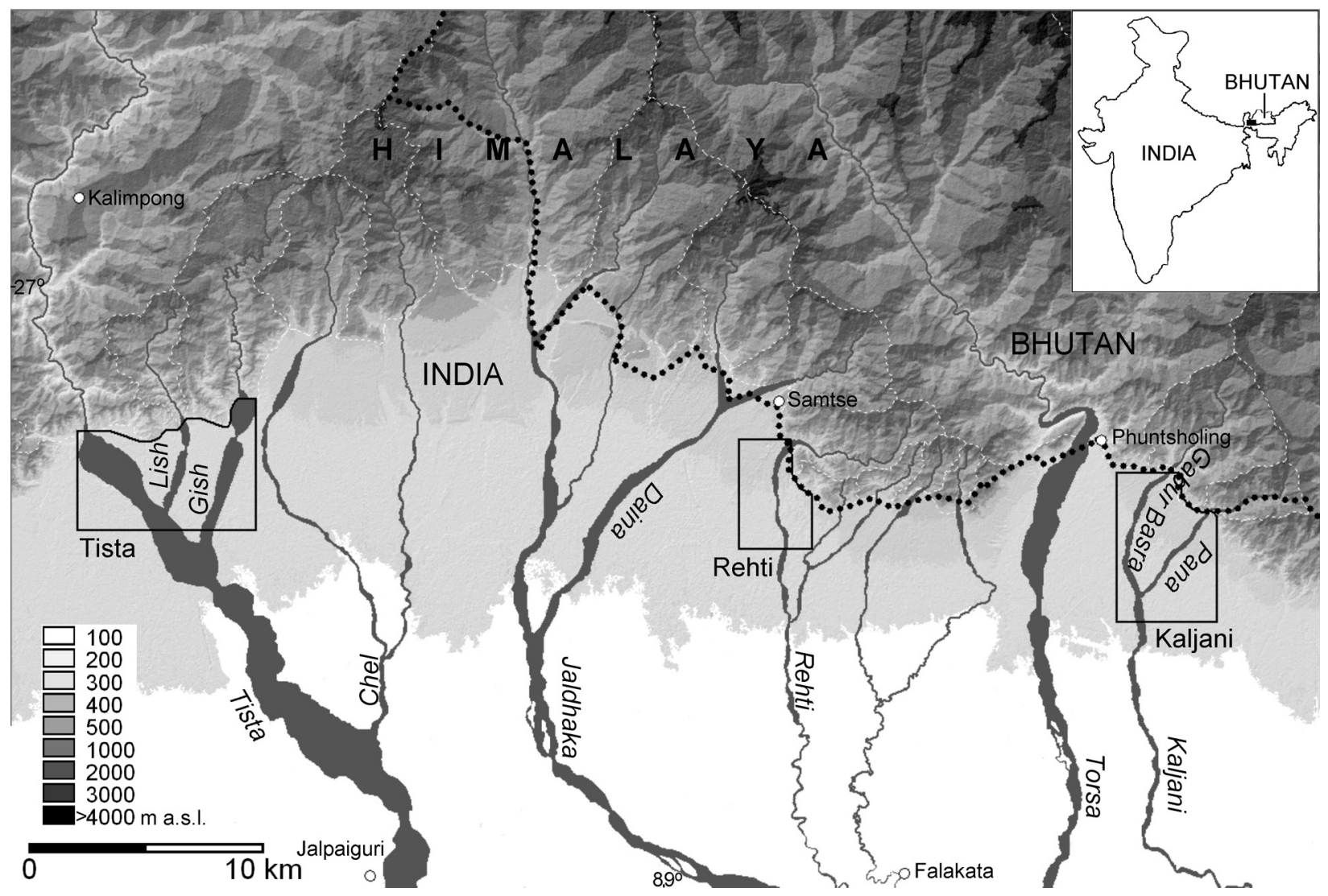

Fig. 1. Margin of the Sikkimese-Bhutanese Himalaya and piedmont zone with selected study sites. White dashed lines indicate watershed divide, black dotted line indicates Indo-Bhutan border.

dargi 2000). In the past three decades the river beds along Himalayan margin experiencing aggradations in between 6-19 $\mathrm{cm}^{\text {year-1 }}{ }^{-1}$ (Sarkar 2008). Thick alluvial cover creates good conditions for water infiltration and during winter season braided channels are totally dry.

A hydrologic and geomorphic approach was employed to delineate three study sites in the piedmont zone along various river courses on alluvial fans. The Tista study site $\left(147.1 \mathrm{~km}^{2}\right)$ is a part of vast fan located at the outlet of the Tista from Himalaya and its two tributaries the Lish and Gish. The large-scale deforestation was initi- ated in Tista region earliest in the whole Dooars through the foundation of tea plantations in between 1874-1885 and the heavy demand for timber for railway construction (Ghosh 1970). The forest preserved only on the higher elevated right bank of Tista and near outlet of Gish. About 78\% of the total population $(37,373$ inhabitants) of the area lives in nine tea gardens. Rest of population is settled along main road and railway at the Himalayan foothills (Census of India 2001).

The Rehti study site $\left(55.6 \mathrm{~km}^{2}\right)$ encompasses fan of river Rehti that receives one small tributary draining edge of the Himalaya. The defores-

Table 1. Characteristic of rivers draining Himalayas and three study sites of piedmont.

\begin{tabular}{|c|c|c|c|c|c|c|}
\hline River & $\begin{array}{l}\text { Mountain } \\
\text { catchment } \\
\left(\mathbf{k m}^{2}\right)\end{array}$ & $\begin{array}{l}\text { River length } \\
\text { in mountains } \\
(\mathbf{k m})\end{array}$ & $\begin{array}{l}\text { River gradient } \\
\text { in mountains } \\
(\%)\end{array}$ & $\begin{array}{l}\text { River length } \\
\text { in piedmont } \\
(\mathrm{km})\end{array}$ & $\begin{array}{l}\text { River gradient } \\
\text { in piedmont } \\
(\%)\end{array}$ & $\begin{array}{c}\text { Study area in } \\
\text { piedmont } \\
\left(\mathbf{k m}^{2}\right)\end{array}$ \\
\hline Tista & $8,637.8$ & 182.0 & 46.4 & 12.4 & 1.9 & \multirow{3}{*}{ Tista: 147.1} \\
\hline Lish & 50.6 & 14.9 & 111.0 & 6.5 & 10.8 & \\
\hline Gish & 157.1 & 32.6 & 60.8 & 11.5 & 7.0 & \\
\hline Rehti & 73.6 & 17.3 & 61.7 & 9.7 & 9.6 & Rehti: 55.6 \\
\hline Gabur-Basra & 103.5 & 14.3 & 121.7 & 11.8 & 10.9 & \multirow{2}{*}{ Kaljani: 107.9} \\
\hline Pana & 33.9 & 10.4 & 179.3 & 9.5 & 15.5 & \\
\hline
\end{tabular}


tation through the foundation of tea plantations was initiated in between 1892-1913 (Ghosh 1970). The large block of the reserved forest is located on the left bank of the river Rehti. Almost whole population (56,334 inhabitants) of the area lives in seven tea gardens (Census of India 2001).

The Kaljani study site $\left(107.9 \mathrm{~km}^{2}\right)$ encompasses a complex fan surface where the two main rivers Gabur-Basra and Pana join together at a distance of $10 \mathrm{~km}$ from the Himalayan margin. The deforestation through the foundation of tea plantations was initiated in between 1894-1913 (Ghosh 1970). Large tea gardens are located at the foothills and southeast of the river Pana. Between these plantations extends W-E belt of reserved forest. About $95 \%$ of the total population $(33,360$ inhabitants) of the area lives in four tea gardens. Rest of popu-

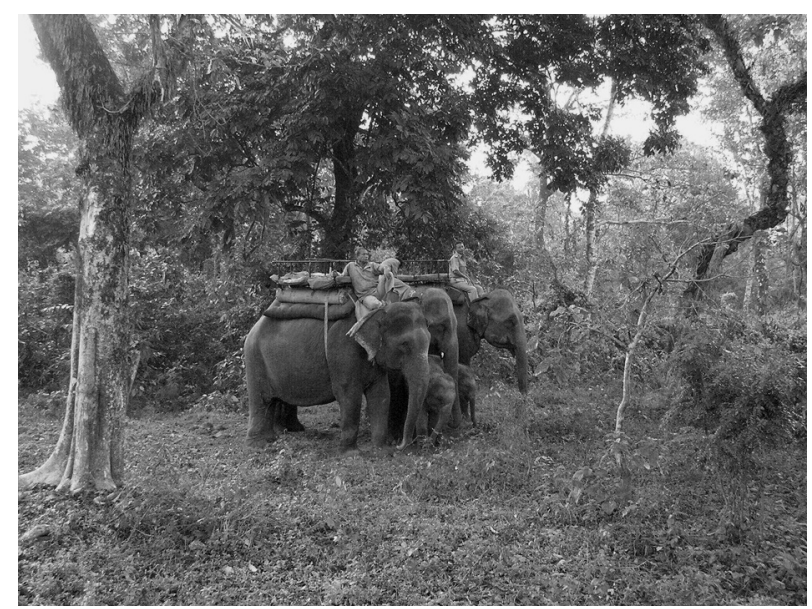

Fig. 2a. Prepared elephants to the tourist safari in Jaldhapara Wildlife Sanctuary between Torsa and Gabur-Basra rivers. The natural forest in the background.

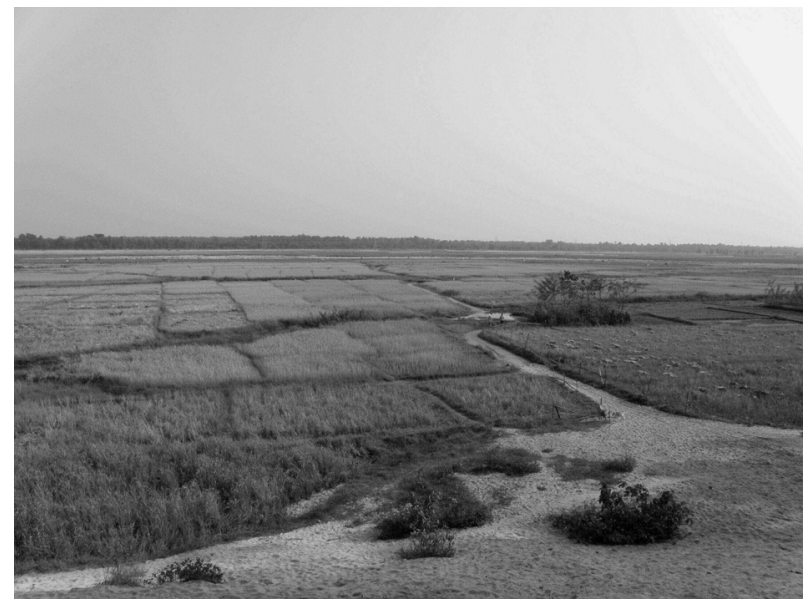

Fig. 2c. Paddy fields at the Gish floodplain. lation is scattered in small villages at the margin of reserved forest (Census of India 2001).

\section{Material and methods}

Historical reports and maps from the British administration were used as the sources of information concerning LULC and population trends of the Himalayan piedmont in the $19^{\text {th }}$ and first three decades of the $20^{\text {th }}$ century. The changes in LULC for a stretch to $10 \mathrm{~km}$ long sections from mountain front were derived from the Survey of India topographic maps at scale 1:63,360 for the year 1930, panchromatic photo images acquired by the American Corona satellite for the year 1970, and satellite images downloaded from Google Earth

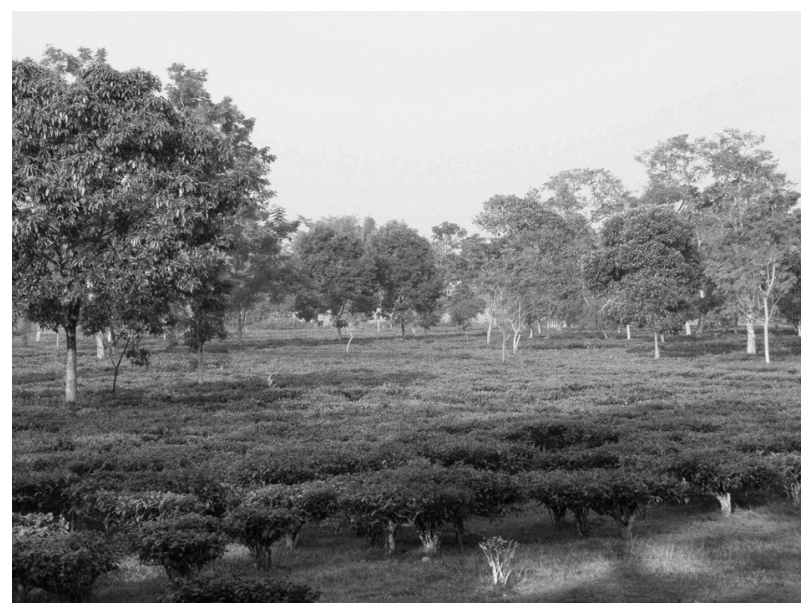

Fig. 2b. Tea plantation at the high terrace near Rehti river.

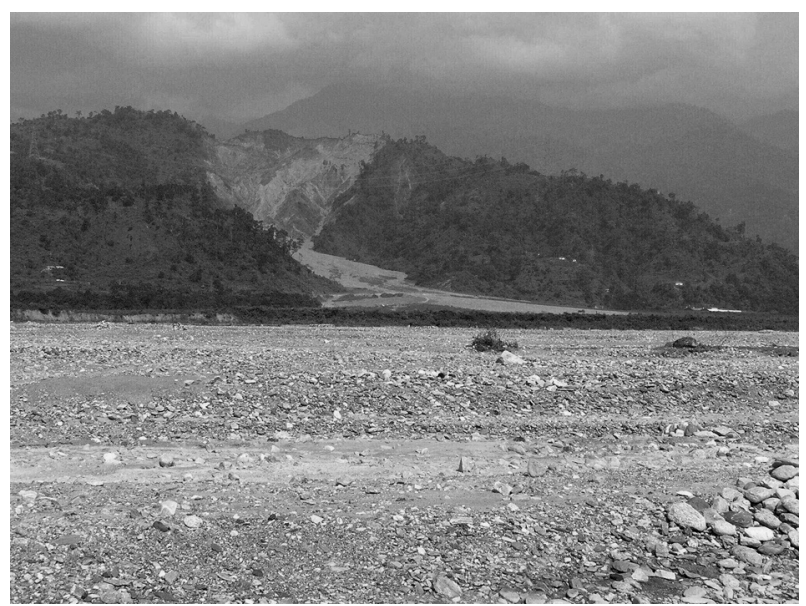

Fig. 2d. Landslide with fan supplying dry Gabur-Basra braided channel at the outlet from Himalaya. 
Pro for the year 2010. Maps and satellite images were supported by tea garden plans/cadastral maps at scales of 1:3,960 for various years between 1930 and 2000. Geometric corrections were performed to rectify all the maps and images into the UTM-45N projection system. Visual interpretation technique combined with several field surveys in between 2007-2011 was used for LULC mapping. In order to standardize the value of maps from three different time periods six consistent LULC categories were defined: forest, grassland, tea plantation, crop cultivation, built-up area and river (Figs 2a-d). Neighbouring catchments draining the Himalayas became combined into three study sites at the piedmont because of common shifts and avulsions of their channels (Table 1). Logical rules in GIS were used for determination where areas has the same land use class in each time period (stable), locations where there had been one point of change between two land use classes on either sides of that area of change (stepped), areas where frequent change has occurred between two categories (cycle) and a high turnover between many different classes (dynamic).

\section{Land use changes}

\subsection{General tendencies in LULC changes up to 1930}

The LULC of Sikkimese-Bhutanese Himalayan piedmont, before annexation from Bhutan to British East India Company in 1864, characterized by large tracts of sal forest intersected by numerous rivers with floodplains overgrown by scattered trees, reed jungle and tall grass (Rennell 1794, Hunter 1876, Fig. 3). Owing to the difficulty of procuring water in the dry winter, the area was only seasonally settled and population density did not exceed 5-10 inhabitants $\mathrm{km}^{-2}$ (Census of India 1872). Shifting agriculture was dominant form of human activity at higher elevated terraces. Paddy cultivation with permanent settlement appeared several kilometers downstream from the mountain front where rivers began to be navigable (Hunter 1876). Environmental conditions of the sparse populated area decided that piedmont was initially categorized as wasteland by Government of Bengal.

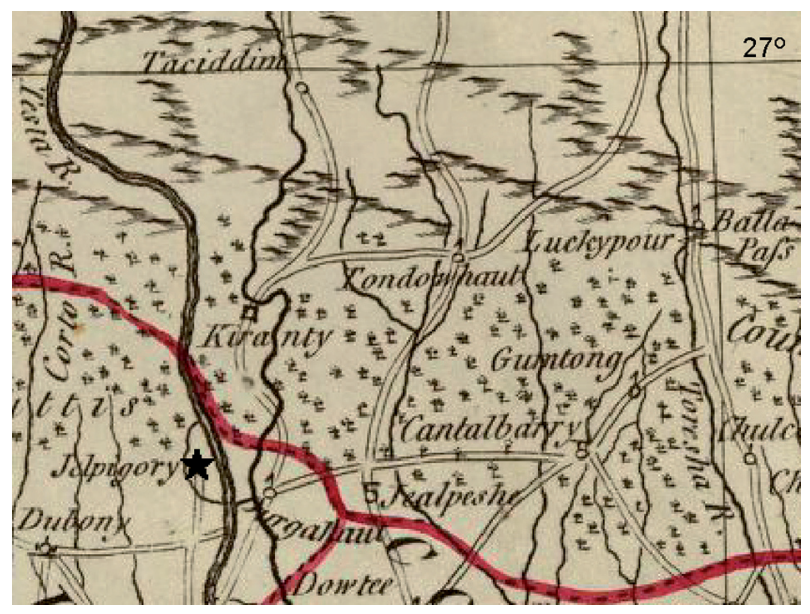

Fig. 3. A part of James Rennell's map to show forested piedmont between Tista and Kaljani (Rennell 1794). Star indicates Jalpaiguri. Thick red line determined southern border of Dooars before the incorporation into the possessions of the British East India Company in 1864.

The perception of the region as void of natural calamities and the successful introduction of tea cultivation in Darjeeling Himalayas (Tista catchment) by 1860 caused leasing out the piedmont for opening tea estates. The first tea garden was established in Gojaldoba on left bank of the river Tista in 1874. Three years later there were 13 tea gardens, covering an area of $3.3 \mathrm{~km}^{2}$ (Allen et al. 1906). Since then, tea cultivation rapidly extended and by 1930, the number of tea gardens increased to 142 covering an area of about 483 $\mathrm{km}^{2}$ (The Indian Tea Association 1930). Development of plantations induced growing demand of work force and migration of laborers towards the extensive tracts of cultivable land east of the Tista (Allen et al. 1906). The recruitment of migrant workers in the initial stages was family based. This strategy ensured cheap labour (including children) permanently settled. Moreover family based migration ensured that labor could be reproduced, thus solving to some extent, the problem of future recruitment (Bhowmik 2002). In effect the population density in piedmont zone reached 60 inhabitants $\mathrm{km}^{-2}$ in 1930 and about $25 \%$ of the population was composed of immigrants from Nepal and Sikkim (Census of India 1931). The formation of LULC framework was finished when the 1865 Forest Act, (strengthened in 1878, amended in 1927) provided the legal instrument for register forest as "reserved" by Forest Department. The 'reservation' process, started from several blocks of natural forest with 
total area of $460 \mathrm{~km}^{2}$, and was continued during independent period (Banarjee et al. 2010).

\subsection{LULC changes between 1930 and 2010}

The majority of area in three investigated sites was not subject to any change in either period (Fig. 4, 5, Table 2). In Tista and Rehti sites LULC with no change shows increasing trend. In case of Rehti site, with highest contribution of stable land, decreasing trend of area with no change is observed. The main processes of LULC change between 1930 and 2010 are deforestation and expansion of the tea plantations. During this period the forest cover in Tista, Rehti and Kaljani site has decreased by $11.1 \%, 10.6 \%$ and $16.6 \%$ respectively. In the first two regions, rate of deforestation was significantly higher in the period 1930-1970 i.e. $9.6 \%$ and $6.7 \%$, while in the last region forest loss was slightly higher in the period 1970-2010 i.e. $9.3 \%$. The dynamic of forest cover change reflects mainly fluvial activity with large floods in 1954 and 1968 that affected western part of the piedmont (Dutt 1966, Starkel 1972) and the several major flood events after 1990 noted in the eastern part (Starkel, Sarkar 2002, Starkel et al. 2008). About $79.4 \%$ and $48.5 \%$ of forest loss in Tista and Kaljani site respectively occurred at the expense of river channel widening or shifting. Only in the Rehti site deforestation was effect of forest clearance for crop cultivation or conversion to grassland. However river course changing lead to direct forest loss in the short period of time, the deforestation is reversible because of forest regrowth within abandoned channels.

The increase rate of tea cultivation was higher in the less economically developed middle and eastern part of piedmont. An area under tea was enlarged only through extension already existed plantations by $3.5 \%$ in Tista, $11.9 \%$ in Rehti and $7.5 \%$ in Kaljani region.

The changes of grassland and crop cultivation does not show clear tendency. These two land use categories occupy mainly floodplains and their area depends on flood events.

Over the past decades there was little change of the built up area pattern. Only in the Tista region continuous growth is observed from 3.3\% in 1930 to $5.7 \%$ in 2010. In the Rehti and Kaljani region built up areas have the same contribution in LULC structure of about $8 \%$ and $5 \%$ respectively. This is an effect of the concentration of the almost whole population in tea gardens which reserved limited area for the settlement development. Large reserved forest areas and frequently inundated floodplains additionally restrict built up expansion.

Comparison of the topographical maps and satellite images indicates that area of river channels increased of about $8.1 \%$ in Tista, $0.8 \%$ in Rehti and 5.5\% in Kaljani between 1930 and 2010. In the first two sites dominates widening of river channels within cultivated floodplains, while in the forested Kaljani site avulsion and changing from meandering to braided river pattern is also observed. These calculations can be little underestimated because of embankments construction along some rivers. The first embankments were constructed only to protect bridges crossing Lish and Gish rivers. In 1978 left bank of Gish was protected between mountain margin and the outlet to Tista. Several kilometers of embankments were constructed in the 1960s and rebuilt later on along right bank of Gabur-Basra to protect forest. Relatively late, in the 1980s embankment was constructed along right bank of Rehti due to progressing westward migration of its channel (cf. Fig. 4). Embankments often prevent channel widening or shifting river courses during local floods. These gave impulse to the expansion of settlement and agriculture closer to the river beds. However extreme flood events cause destruction of embankments and direct loss of forest, crops and settlement.

\subsection{LULC dynamic}

The study of LULC changes revealed that the stable land use dominates in all investigated regions and covers $57 \%$ of Tista, $54 \%$ of Rehti and $67 \%$ of Kaljani total area (Fig. 6). Stable land use area mainly consists of large blocks of reserved forest, tea gardens and settlement cores.

About $1 / 3$ of each study area undergone stepped changes. These are usually conversion of forest or grassland to tea bushes at the margin of tea gardens. Natural changes in this category are concentrated along river banks. They are related 

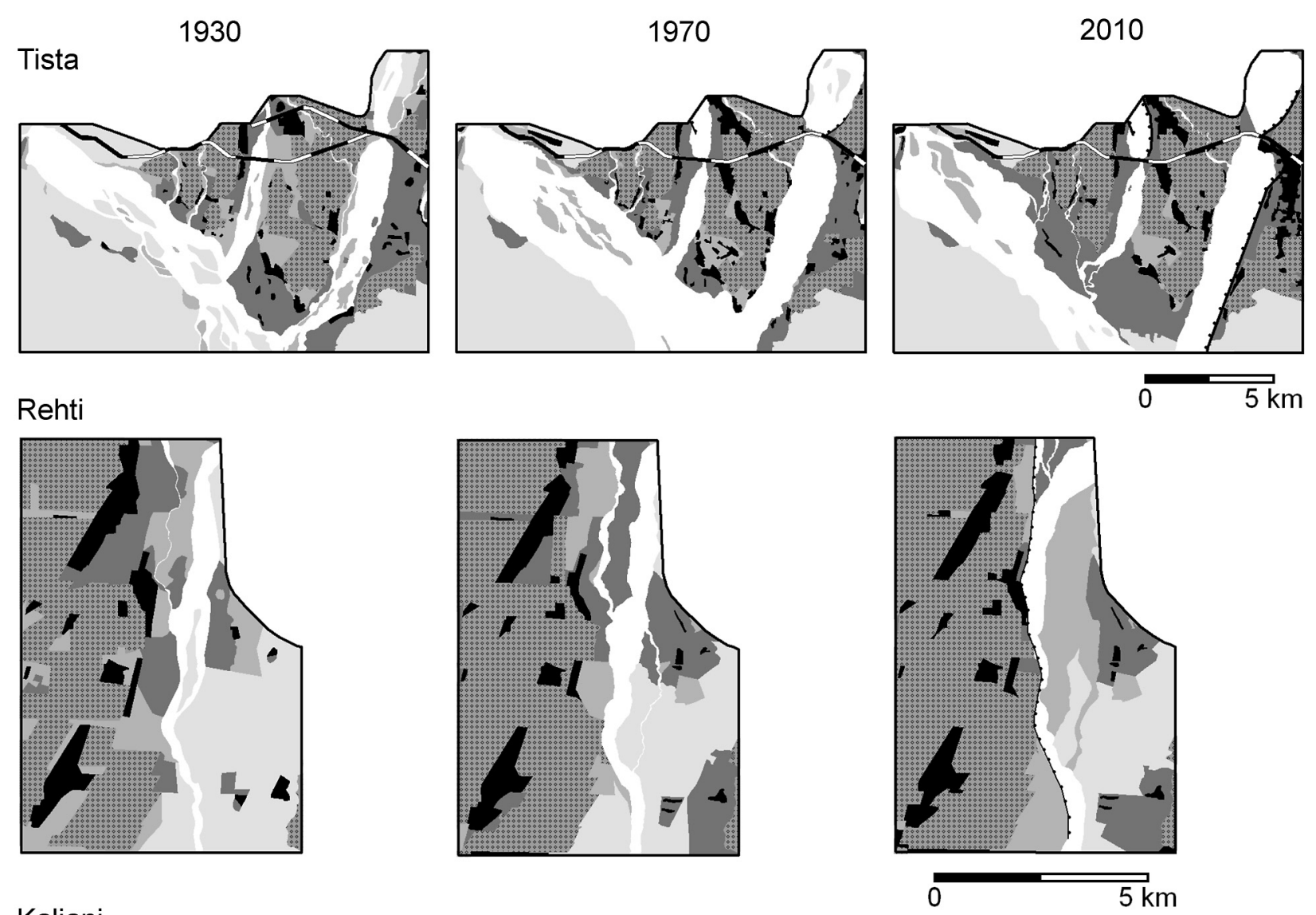

Kaljani
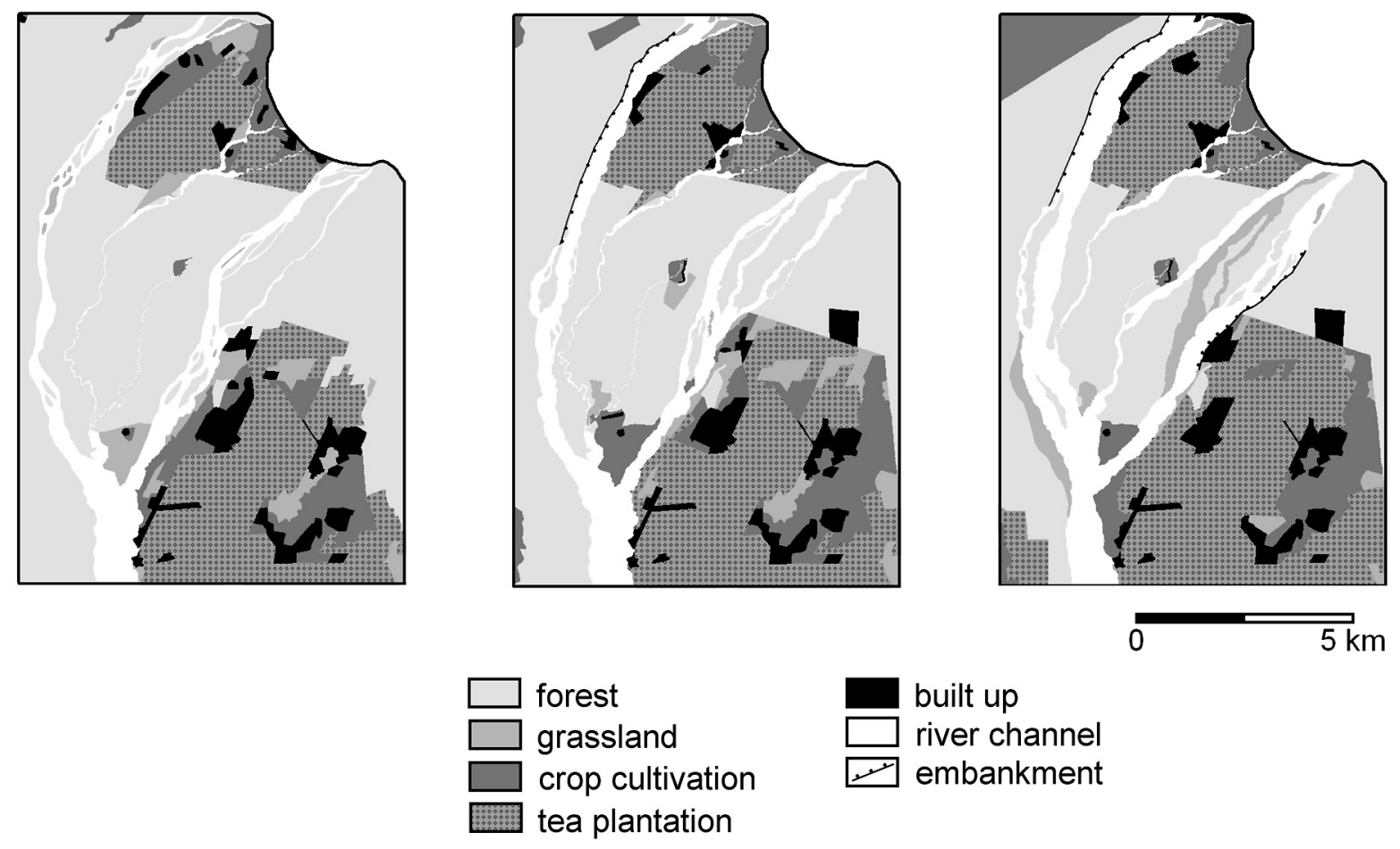

Fig. 4. Spatial distribution of LULC in the selected study sites. 

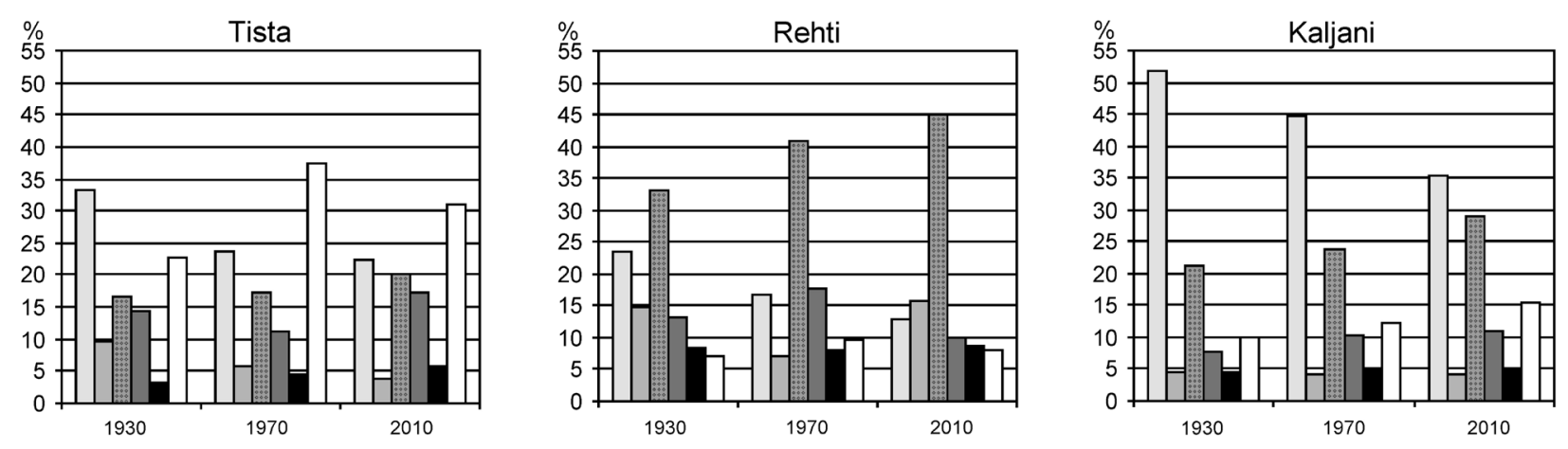

$\square$ forest

E.:- tea plantation

2010

$\square$ crop cultivation

built up

river channel

Fig. 5. Percentage contribution of LULC categories in the selected study sites.

Table 2. Predominant types of LULC changes (claiming over $1 \%$ of the total area).

\begin{tabular}{|c|c|c|c|c|c|c|}
\hline \multirow{2}{*}{ Type of LULC change } & \multicolumn{2}{|c|}{ Tista } & \multicolumn{2}{|c|}{ Rehti } & \multicolumn{2}{|c|}{ Kaljani } \\
\hline & 1930-1970 & $1970-2010$ & 1930-1970 & $1970-2010$ & 1930-1970 & 1970-2010 \\
\hline No change & 72.1 & 75.0 & 66.1 & 74.3 & 82.2 & 79.6 \\
\hline Forest to grassland & 1.6 & & & 3.5 & 1.9 & \\
\hline Forest to crop cultivation & & & 4.9 & & 2.9 & 2.7 \\
\hline Forest to river & 7.2 & 3.2 & 2.2 & & 4.5 & 5.2 \\
\hline Grassland to tea & & & 5.7 & 1.9 & & 1.7 \\
\hline Grassland to crop cultivation & 1.3 & & 6.3 & & 1.1 & \\
\hline Grassland to river & 4.3 & 1.4 & & 1.3 & & \\
\hline Crop cultivation to grassland & & & 5.5 & 3.2 & & \\
\hline Crop cultivation to tea & & 1.5 & 1.5 & 2.8 & 1.6 & 2.2 \\
\hline Crop cultivation to built up & 1.4 & 2.2 & & & & \\
\hline Crop cultivation to river & 5.1 & & & 2.7 & & \\
\hline Built up to crop cultivation & & & 1.3 & & & \\
\hline River to forest & & 1.1 & & & 2.4 & \\
\hline River to grassland & 1.2 & 1.7 & & 5.9 & & 2.1 \\
\hline River to crop cultivation & & 9.3 & & & & \\
\hline
\end{tabular}

to widening and conversion of meandering to braided river channels or their avulsion.

Cycle changes occur only in places within distal areas of the large river floodplains such as Tista, Gish and Rehti. Margins of their wide floodplains are occupied by paddy fields. During extreme floods the cultivated land is affected by debris deposition and excluded from cultivation. Usually after some time sediment is removed or mixed with soil and land is again taken under cultivation. The area under cycle changes covers $6 \%$ of Tista, $4 \%$ of Rehti and only $1 \%$ of Kaljani region.

Dynamic changes of land use occupy only $4 \%$ of total area of the Tista and Kaljani but recorded higher contribution i.e. $10 \%$ in case of Rehti area. Land undergoing this high turnover between many different land use classes is scat- tered within Tista, Rehti and Pana river channels where gravel and sand bars are frequently degraded and built up by flowing water. In case of Rehti such changes are related to progressive migration of its bed to the west and construction of embankments leading to extension of crop cultivation and settlement closer river channel. Minor dynamic changes are also observed in the case of settlement expansion at the expense of various land use categories.

\section{Discussion}

LULC changes of piedmont zone are result of interaction between natural forces and human activity. The changes in the area of tea gardens, built up and crop cultivation are related directly 


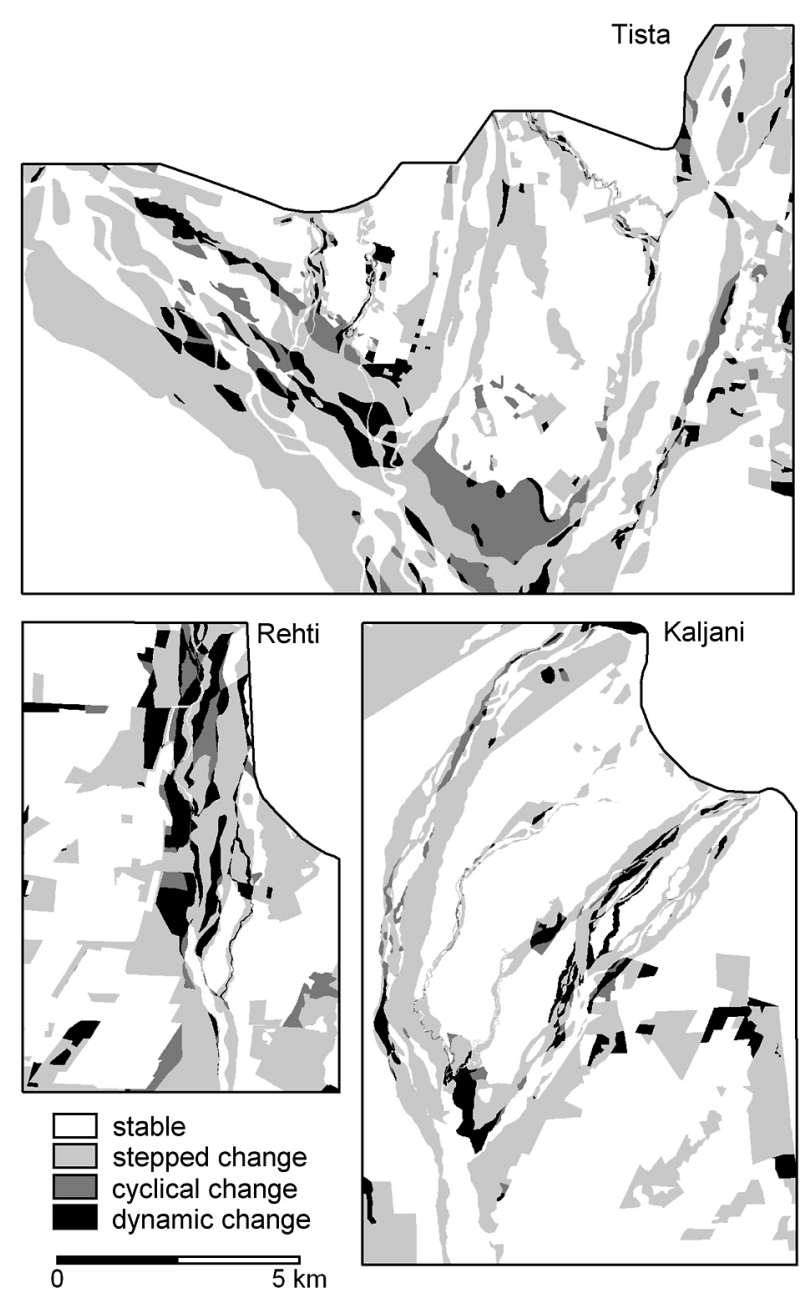

Fig. 6. LULC stability between 1930 and 2010.

to human impact. Land occupied by these three categories increased from $34 \%$ to $43 \%$ in Tista, from $55 \%$ to $64 \%$ in Rehti and from $34 \%$ to $45 \%$ in Kaljani between 1930 and 2010.

The tea cultivation is long term monoculture. About $43 \%$ of tea bushes are more than 50 years old (Tea Board... 2010). The land for the plantations belongs to Government and is given in lease to the employers. Each lease has to be renewed after 30 years, and is subject to the condition that the land will be used for tea production alone (Bhowmik 2002). Therefore extension of tea cultivation increases LULC stability. Tea estates also provide residential quarters for their employees along with some community facilities like school, hospital and other socio-cultural institutes, which cover a significant portion of grant area. Besides these most of the tea estates still occupy some more land (between 10 and 35\% of the total granted area) where no activity is performed.
This area can be potentially taken under tea cultivation. The decision about the extension of cultivation often causes change in two other land use categories. Larger area under tea requires new labourers - immigrants or local people. Induced population growth leads in turn to extension of built up area and crop cultivation for supplying growing food needs.

The growing population trend from 280 inhabitants $\mathrm{km}^{-2}$ in 1971 to 546 inhabitants $\mathrm{km}^{-2}$ in 2001 is noticed in the whole Jalpaiguri District (Census of India 2001). Our three investigated sites also show high population density of about 254, 842 and 309 inhabitants $\mathrm{km}^{-2}$ in Tista, Rehti and Kaljani areas respectively. Despite that only minor changes in built up area are observed. This is effect of specific land use pattern within plantation. Most workers of the tea gardens reside within the plantation area restricted by so-called "labour lines", delimited already during formation of garden. The basic material for building is provided by employer and the worker is expected to construct his hut but within strictly delimited parcel. Therefore changes in built up pattern are restricted to small area despite construction of new buildings. Only Tista site, where $22 \%$ of population lives outside tea gardens, notice high changes between built up and crop cultivation categories (cf. Fig. 4, Table 2).

Introduction of silviculture caused opposite to described earlier human activity concentrated on preservation remnants of natural forest. During last decades, when was recorded the high population growth, the area of forest increased from $1602 \mathrm{~km}^{2}$ in 1988 to $1864 \mathrm{~km}^{2}$ in 2006 in the Jalpaiguri District (Government West Bengal 20082009). Our analysis indicates the fluvial activity as a main deforestation agent in all three sites (cf. Table 2). Significant, but smaller forest loss related to human activity (at the expense of cultivation) occurred within floodplain of Rehti and close to the Himalayan foothills in the Kaljani area. Relatively low population pressure on forest and forest transition at the scale of the whole Jalpaiguri District seems to be effect of overlapping forest policy and economic development pathways (Rudel et al. 2005, Lambin \& Meyfroidt 2010).

First pathway is realized through establishment of national parks and protected wildlife 
sanctuaries, implementation of ban on illegal timber extraction, location of forest villages to secure permanent labour force for fire protection, development of tree plantations, introduction of Joint Forest Management through formation of Forest Protection Committees or embankments construction along main rivers against floods (Trafford 1905, Karlsson 2000, Government West Bengal 2008-2009, DeFries \& Pandey 2010). Through these activities for instance problem of forest margin encroachment was reduced significantly in comparison to several decades back. However still about $260 \mathrm{~km}^{2}$ of forest area in the Jalpaiguri District is affected by illegal timber extraction and conversion for agriculture (Government West Bengal 2008-2009).

Second pathway can be connected with employment system in tea plantations where most of the population is concentrated. The distinctive feature of this system is the high proportion of women in the labour force (they constitute more than half of workers) and the employment of child labour according to The Plantation Labour Act of 1951. Moreover as per an industry wise agreement, the son or daughter of a worker who has retired has to be hired in the place of his/her father or mother. Through this families have assured jobs for at least one member of the family (Bhowmik 2002). Seems that this system of employment creates enough non-farm jobs to pull farmers off of the forest and therefore at least help in stabilization LULC pattern of piedmont. In our case simple population growth and high population density cannot explain predominant LULC changes as it was also presented in several other tropical areas (Mather \& Needle 2000, Turner et al. 2001, Carr 2004, Rudel et al. 2005).

More difficult is investigation of causes of river widening and avulsion. Topographic maps of 1930s show that most of the studied rivers maintained their braided pattern with stabilized sand and gravel bars covered by vegetation. The braided patterns reflect erosive conditions, which resulted in high flood discharges and sediment supply. Between 1930 and 2010 channel widening and decrease of gravel bars was noted in all of the studied rivers. This phenomenon can be considered as a overlapping of natural rainfallrunoff regime and human induced fluvial adjustment, related to deforestation of mountain catchments and riparian zones of piedmont.

Annual and seasonal rainfall series are stable over Sikkim Himalaya and piedmont zone during the last 150 years, but the monsoon is highly variable in intensity from year to year (Parthasarathy et al. 1995). Extreme floods on Tista and its tributaries in 1954 and 1968 caused widening river channels of about $14.7 \%$ in the period 1930-1970. Subsequent decrease of channel area between 1970 and 2010 is the result of a recovery process in response to their earlier destabilization. Nevertheless, river channels occupied of about $8.1 \%$ larger area of Tista in 2010 in comparison to 1930. Higher rate of channel widening of $3.4 \%$ in the period $1970-2010$ in comparison to $2.1 \%$ in the period 1930-1970 is also observed in Kaljani area in response to clustering of heavy rain events and floods since the 1990s (Starkel \& Sarkar 2002).

Changes in land use from forested to agricultural in headwater areas are known to increase discharge and sediment supply influencing downstream channel morphology in complex ways (Liebault \& Piegay 2002, Price \& Leigh 2006, Wohl 2006). Highest rates of channel widening in the Lish and Gish draining Indian Sikkimese Himalayas can be related to widespread deforestation of their mountain catchments (Table 3), high population density (about 200 inhabitants $\mathrm{km}^{-2}$ ) and surface coal mining followed several decades ago (Basu \& Ghatowar 1988, 1990). Lowest rates of channel widening are observed in the case of Rehti and Kaljani. Their mountain catchments, draining Bhutanese Himalayas, are less deforested and ten times less populated in com-

Table 3 . Forest cover and its changes in mountain catchments.

\begin{tabular}{|c|c|c|c|c|c|c|}
\hline \multirow{2}{*}{ River } & \multicolumn{3}{|c|}{ Forest cover (\%) } & \multicolumn{2}{c|}{ Forest cover increase (+)/decrease (-) } \\
\cline { 2 - 7 } & $\mathbf{1 9 3 0}$ & $\mathbf{1 9 7 0}$ & $\mathbf{2 0 1 0}$ & $\mathbf{1 9 3 0 - 1 9 7 0}$ & $\mathbf{1 9 7 0 - 2 0 1 0}$ & $\mathbf{1 9 3 0 - 2 0 1 0}$ \\
\hline Lish & 74.8 & 69.8 & 66.5 & -5.0 & -3.3 & -8.3 \\
\hline Gish & 83.4 & 79.2 & 77.8 & -4.2 & -1.4 & -5.6 \\
\hline Rehti & 74.6 & 80.4 & 84.7 & +5.8 & +4.3 & +10.1 \\
\hline Gabur-Basra & 93.2 & 88.0 & 87.7 & -5.2 & -0.3 & -5.5 \\
\hline Pana & 92.3 & 82.2 & 81.5 & -10.1 & -0.7 & -10.8 \\
\hline
\end{tabular}


parison to Indian Sikkimese Himalayas (Office of the Census... 2006).

Channel geometry can be also strongly influenced by local controls such as the riparian vegetation cover of banks. Dense vegetation increase roughness and, via binding effects of the roots, increases bank resistance to erosion (Millar 2000). The channel widening together with accretion of river beds and gradual decrease of gravel bars can indicate reduction of roughness of river banks related to forest degradation on river margins and human intensive floodplain uses. This is especially visible in the case of Lish, Gish and partly Rehti before construction of embankment in the 1980s.

\section{Conclusions}

The piedmont of Sikkimese-Bhutanese Himalayas is characterized by a shift from natural towards human-dominated landscape over the last 150 years. The LULC transformation marked three distinct periods. The forest vegetation, fluvial activity adjusted to natural rainfall-runoff regime and sparse population prevailed up to annexation piedmont into British East India Company in 1864 . Second period distinguished rapid deforestation connected with the location of tea plantations on higher elevated terraces, expansion of settlement and taking floodplains under crop cultivation. Introduction of forestry finalized the formation of a new LULC framework. Third period between 1930 and 2010 marked the gradual extension of tea gardens and intensive crop cultivation within floodplains as well as development of forestry. The main effect of human impact on LULC during investigated period is the gradual increase of the land use stability through the enlargement of areas with monoculture cultivation of tea and paddy. However present-day contribution of stable land use has not reached the level from period when piedmont was covered by natural forest.

The piedmont is an example where in humandominated landscape with the high population density natural agents play still important role in LULC changes. The fluvial activity became primary factor of present-day LULC changes. The widening and avulsion of river channels, chang- ing from meandering to braided, their pattern, decreasing of vegetation stabilized gravel bars noted in all investigated areas is result of interaction between natural forces and human impact.

Natural forces related to influence of the adjacent Himalayas, consisting mainly of tectonic uplift, intensively weathered and non-resistant lithological conditions, as well as high intensity monsoon precipitation, are most powerful factors of water and sediment flux into piedmont zone. The human induced deforestation of mountain catchments or intensive cultivation of piedmont floodplains play important but secondary role in intensification of fluvial activity.

High rainfalls, floods, river bank erosion or channel avulsion are not new extreme phenomena for this region. However with settlement development and changing LULC pattern, increase vulnerability of region to such hazards. Present observations seems to be indicative of land use trends in Eastern Himalayan piedmont generally, particularly as tea plantations and floodplain crop cultivation expand to the east into neighboring Assam.

\section{Acknowledgements}

The presented study was realized as a product of a bilateral exchange program between the Polish Academy of Sciences and the Indian National Science Academy.

\section{References}

Allen B.C., Gait E.A., Howard H.F. \& Allen C.G.H., 1906. Gazetteer of Bengal and North-East India. Mittal Publication, New Delhi.

AN L., 2012. Modeling human decisions in coupled human and natural systems: Review of agent-based models. Ecological Modelling, 229: 25-36, DOI: 10.1016/j.ecolmodel.2011.07.010.

AN L. \& CARR D.L., 2012. Understanding human decisions in coupled natural and human systems. Ecological Modelling, 229: 1-4, DOI: 10.1016/j.ecolmodel.2011.10.023.

Banarjee A., Ghosh S. \& Springate-Baginski O., 2010. The creation of West Bengal's forest underclass an historical institutional analysis of forest rights deprivations. IPPG Discussion Papers, 51: 1-26.

BASU S.R. \& GHATOWAR L., 1988. Landslides and soil-erosion in the Gish drainage basin of the Darjeeling Himalaya and their bearing on North Bengal floods. Studia Geomorphologica Carpatho-Balcanica, 22: 105-122. 
BASU S.R. \& GHATOWAR L., 1990. The impact of landslides on fluvial processes in the Lish basin of the Darjeeling Himalayas. Geographia Polonica, 59: 77-87.

BHANDARI L. \& KALE S. (eds.), 2009. Indian states at a glance 2008-09: West Bengal: performance, facts and figures. Indicus Analitycs, New Delhi.

Bношмік S.K., 2002. Productivity and labour standards in tea plantation sector in India. In: Sivananthiran A., Venkata Ratnam C.S. (eds.), Labour and social issues in plantations in South Asia. International Labour Organisation, New Delhi: 133-166.

BoOKHAGEN B., 2010. Appearance of extreme monsoonal rainfall events and their impact on erosion in the Himalaya. Geomatics, Natural Hazards and Risk, 1(1): 37-50, DOI: 10.1080/19475701003625737.

CARr D.L., 2004. Proximate population factors and deforestation in tropical agricultural frontiers. Population and Environment, 25(6): 585-612, DOI: 10.1023/B:POEN.000003 $9066.05666 .8 \mathrm{~d}$.

CArr D.L., Suter L. \& Barbieri A., 2006. Population dynamics and tropical deforestation: State of the debate and conceptual challenges. Population and Environment, 27(1): 89-113, DOI: 10.1007/s11111-005-0014-x.

Chowdhury R.R. \& Turner B.L. II, 2006. Reconciling agency and structure in empirical analysis: smallholder land use in the Southern Yucatán, Mexico. Annals of the Association of American Geographers, 96(2): 302-322.

Census of India, 1872. Bengal. Calcutta.

Census of India, 1931. Bengal and Sikkim. Vol. V \& VI, Calcutta.

Census of India, 2001. West Bengal. New Delhi.

Champion H.G. \& Seth S.K., 1968. A revised survey of forest types of India. Manager Publication, Delhi.

Davidar P., Sahoo S., Mammen P.C., Acharya P., Puyravaud J.-P., Arjunan M., Garrigues J.P. \& Roessing K., 2010. Assessing the extent and causes of forest degradation in India: where do we stand? Biological Conservation, 143: 2937-2944, DOI: 10.1016/j.biocon.2010.04.032.

DeFries R., 2008. Terrestrial vegetation in the coupled humanearth system: Contributions of remote sensing. Annual Review of Environment and Resources, 33: 369-390, DOI: 10.1146/annurev.environ.33.020107.113339.

DeFries R, Karanth K.K. \& Pareeth S., 2010, Interactions between protected areas and their surroundings in humandominated tropical landscapes. Biological Conservation, 143: 2870-2880, DOI: 10.1016/j.biocon.2010.02.010.

DeFries R. \& PAndey D., 2010. Urbanization, the energy ladder and forest transitions in India's emerging economy. Land Use Policy, 27: 130-138, DOI:10.1016/j.landusepol.2009.07.003.

Dhar O.N. \& NANDARGi S., 2000. A study of floods in the Brahmaputra basin in India. International Journal of Climatology, 20: 771-78.

DutT G.N., 1966. Landslides and soil erosion in the Kalimpong Subdivision, Darjeeling district and their bearing on the North Bengal Flood. Bulletin of the Geological Survey of India, Series B, 15(1): 62-69.

Froehlich W. \& Starkel L., 1987. Normal and extreme monsoon rains - their role in shaping of the Darjeeling Himalaya. Studia Geomorphologica Carpatho-Balcanica, 21: 129-160.

Froehlich W., Starkel L., 1993. The effects of deforestation on slope and channel evolution in the tectonically active Darjeeling Himalaya. Earth Surface Processes Landforms, 18: $285-290$
Froehlich W. \& WALLing D.E., 2007. The use of environmental radionuclides in investigations of sediment sources and overbank sedimentation rates in the Himalaya Foreland, India. In: Hubert P., Schertzer D., Takeuchi K. \& Koide S. (eds.), Predictions in ungauged basins: PUB Kick-off proceedings of the PUB Kick-off meeting held in Brasilia, 20-22 November 2002. IAHS Publication, 309: 137-145.

Geist H.J. \& Lambin E.F., 2002. Proximate causes and underlying driving forces of tropical deforestation. BioScience, 52(2): 143-150.

Geist H.J. \& Lambin E.F. (eds.), 2006. Land use and land cover change: Local processes, global impacts. The IGBP Book Series, Springer-Verlag, Berlin.

GHosh B.C., 1970. The development of tea industry in the District of Jalpaiguri. In: Sanyal J.C., Ghose G.C., Chakraborty J.C. (eds.), Jalpaiguri District centenary souvenir 1879-1968: 281-310.

GHOSH S. \& CARranZA E.J.M., 2010. Spatial analysis of mutual fault/fracture and slope controls on rocksliding in Darjeeling Himalaya, India. Geomorphology, 122: 1-24, DOI: 10.1016/j.geomorph.2010.05.008.

Government West Bengal, 2008-2009. State forest report West Bengal. Directorate of Forests, Kolkata.

Grujic D., Coutand J., Bookhagen B., Bonnet S., Blythe A. \& DunCAN CH., 2006. Climatic forcing of erosion, landscape and tectonics in the Bhutan Himalaya. Geological Society of America, 34(10): 801-804, DOI:10.1130/G22648.1.

HunTER W.W., 1876. A statistical account of Bengal. Vol. X. Trubner \& Co., London.

KarLsson B., 2000. Contested belonging: An indigenous people's struggle for forest and identity in Sub-Himalayan Bengal. Curzon Press, Richmond, Surrey, UK.

Lambin E.F., Geist H.J. \& Lepers E., 2003. Dynamics of landuse and land-cover change in tropical regions. Annual Review of Environment and Resources, 28: 205-241.

LAmbin E.F. \& Meyfroidt P., 2010. Land use transitions: Socio-ecological feedback versus socio-economic change. Land Use Policy, 27: 108-118, DOI: 10.1016/j.landusepol.2009.09.003.

Liebault F. \& Piegay H., 2002. Causes of $20^{\text {th }}$ century channel narrowing in mountain and piedmont rivers of southeastern France. Earth Surface Processes and Landforms, 27: 425-444.

Mather A.S. \& NeEdLe C.L., 2000. The relationships of population and forest trends. The Geographical Journal, 166(1): 2-13.

MAdHUSUDAN K., 2011. Nature tourism development and impact assessment in peripheral areas - a study of North Bengal (India). South Asian Journal of Tourism and Heritage, 4(1): 90-99.

Millar R.G., 2000. Influence of bank vegetation on alluvial channel patterns. Water Resources Research, 36(4): 11091118.

NAKATA T., 1972. Geomorphic history and crustal movements of the foot-hills of the Himalayas. The Scientific Reports of the Tohoku University, 7th Series, Geography, 22: 39-177.

Office of the Census Commissioner Royal Government of Bhutan, 2006. Results of population and housing census of Bhutan 2005. Kuensel Corporation Ltd., Thimphu, Bhutan.

Parthasarathy B., Munot A.A. \& Kothawale D.R., 1995. All India monthly and seasonal rainfall series: 1871-1993. Theoretical and Applied Climatology, 49: 217-224.

Persha L., Fischer H., Chhatre A., Agraval A. \& Benson C., 2010. Biodiversity conservation and livelihoods in hu- 
man-dominated landscapes: Forest commons in South Asia. Biological Conservation, 143(12): 2918-2925, DOI: 10.1016/j.biocon.2010.03.003.

Price K. \& Leigh D.S., 2006. Morphological and sedimentological responses of streams to human impact in the southern Blue Ridge Mountains, USA. Geomorphology, 78: 142-160, DOI: 10.1016/j.geomorph.2006.01.022.

RAY S., 2002. Transformations on the Bengal Frontier: Jalpaiguri, 1765-1948. Routledge Curzon, London.

RenNell J., 1794. A map of the north part of Hindostan or a geographical survey of the Provinces of Bengal, Bahar, Awd, Ellahabad, Agra and Delhi. Laurie \& Whittle, London.

Rudel T., Coomes O., Moran E., Achard F., Angelsen A., Xu J. \& LAMBin E., 2005. Forest transitions: towards a global understanding of land use change. Global Environmental Change, 15: 23-31, DOI: 10.1016/j.gloenvcha.2004.11.001.

SARKAR S., 1996. Impact of catastrophic erosion in the fluvial dynamics of the river Mahananda, Darjeeling Himalaya. In: Singh R.B. (ed.), Research in Geography: Disaster and Environment. APH Publications, New Delhi, 2: 337-348.

SARKAR S., 2004. Hydro-meteorological study of high intensity rainstorms in the upper Tista basin. In: Singh S., Sharma H.S., De S.K. (eds.), Geomorphology and Environment. ACB Publications, Kolkata: 34-53.

SARKAR S., 2008. Flood hazard in the Sub-Himalayan North Bengal, India. In: Singh S., Starkel L., Syiemlieh H.J. (eds.), Environmental Changes and Geomorphic Hazard. Bookwell, New Delhi, Shillong: 247-262.

STARKEL L., 1972. The role of catastrophic rainfall in the shaping of the relief of the Lower Himalaya (Darjeeling Hills). Geographia Polonica, 21: 103-147.

StARKel L. \& BASU S. (eds.), 2000. Rains, landslides and floods in the Darjeeling Himalaya. INSA, New Delhi.

STARKEL L. \& SARKAR S., 2002. Different frequency of threshold rainfalls transforming the margin of Sikkimese and Bhutanese Himalaya. Studia Geomorphologica Carpatho-Balcanica, 36: 51-67.
Starkel L., Sarkar S., Soja R. \& Prokop P., 2008. Present-day evolution of the Sikkimese-Bhutanese Piedmont. Prace Geograficzne IGiPZ PAN, 219.

SOJA R. \& STARKEL L., 2007. Extreme rainfalls in Eastern Himalaya and southern slope of Meghalaya Plateau and their geomorphological impacts. Geomorphology, 84: 170-180, DOI: 10.1016/j.geomorph.2006.01.040.

Tea Board of India, 2010. List of new registration of Tea Estate during 1900-2010. Licensing Department, Kolkata.

The Indian Tea Association, 1930. Maps of tea districts with complete index to tea gardens. The Indian Tea Association, Calcutta.

TIwARI P.C., 2000. Land-use changes in Himalaya and their impact on the plains ecosystem: need for sustainable land use. Land Use Policy, 17: 101-111.

TRAFFORD F., 1905. Working plan for the reserved forest of the Jalpaiguri Division. Darjeeling. Bengal Secretariat Tour Press, Darjeeling.

TURNER B.L. II., 2001. Toward integrated land-change science: Advances in 1.5 decades of sustained international research on land-use and land-cover change. In: Steffen W. (ed.), Advances in Global Environmental Change Research. Springer, Berlin, New York.

Turner II B.L., Geoghegan J., Keys E., Klepeis P., Lawrence D., Mendoza P.M., Manson S., Ogneva-Himmelberger Y., Plotkin A.B., Salicrup D.P., Chowdhury R.R, SAvitsky B., Schneider L., Schmook B., Vance C., Villar S.C. \& Foster D., 2001. Deforestation in the southern Yucata'n peninsular region: An integrative approach. Forest Ecology and Management, 154(3): 353-370.

WoHL E., 2006. Human impacts to mountain streams. Geomorphology, 79: 217-248, DOI: 10.1016/j.geomorph.2006.06.020.

Zvoleff A. \& An L. The ChitwanABM: modeling feedbacks between population and land-use in the Chitwan Valley, Nepal. Ecological Modelling. Submitted for publication. 